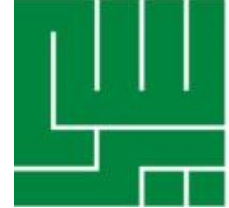

KATA KUNCI

KEYWORDS

ABSTRAK

ABSTRACT

\section{PERAN DUKUNGAN SOSIAL KELUARGA TERHADAP MOTIVASI MENJAGA KESEHATAN MELALUI AKTIVITAS FISIK PADA LANSIA}

\section{The Role of Familial Social Support Towards Health- Maintaining Motivation Through Physical Activities in Older Adults}

\author{
Rizka Ahadiningtyas Juliana Atmaja ${ }^{1}$, Rina Rahmatika ${ }^{2}$ \\ 1,2 Fakultas Psikologi Universitas YARSI, Jakarta, Indonesia \\ rizka.ahadiningtyas@gmail.com
}

Lansia, Dukungan Sosial Keluarga, Motivasi Menjaga Kesehatan

Older Adults, Familial Social Support, Health-Maintaining Motivation

Individu yang telah lanjut usia (lansia) mengalami penurunan fungsi fisik seiring bertambahnya usia, oleh karena itu diperlukan dorongan untuk melakukan aktivitas fisik dalam menjaga kesehatan. Salah satu hal yang diperlukan adalah dukungan dari berbagai pihak seperti misalnya dukungan sosial keluarga. Tujuan dari penelitian adalah untuk mengetahui peran dari dukungan sosial keluarga terhadap motivasi menjaga kesehatan melalui aktivitas fisik pada lansia. Partisipan penelitian ini berjumlah 101 orang lansia dengan kisaran usia 60-84 tahun $(\mathrm{M}=65,64 ; \mathrm{SD}=5,973)$ di Jakarta. Teknik sampling yang digunakan dalam penelitian ini adalah incidental sampling. Alat ukur yang digunakan dalam penelitian ini adalah Social Provisions Scale yang telah diadaptasi ke dalam bahasa Indonesia, untuk mengukur dukungan sosial keluarga dan Health Motivation in Physical Activity sebagai alat ukur motivasi menjaga kesehatan melalui aktivitas fisik. Hasil dari penelitian ini menunjukkan bahwa dukungan sosial keluarga berperan signifikan terhadap motivasi menjaga kesehatan melalui aktivitas fisik pada lansia $\left(\mathrm{R}^{2}=0,072 ; p=<0,05\right)$. Hasil tersebut memiliki arti bahwa dukungan sosial keluarga memiliki peran sebesar 7,2\% terhadap motivasi menjaga kesehatan terhadap lansia yang melakukan aktivitas fisik.

Some cases show that physical function decreases in elderly age, so it become a concern for elderly people to do physical activities in order to maintain their physical performance. Familial social support perceived as one aspect that may has role to encourage elderly people to do physical activity. This study aimed to investigate role of familial social support to health-maintaining motivation through social activity in elderly people. Sample of this study is 101 elderly people whose age are between 60 to 84 years old $(M=65.64 ; S D=5.973)$, and incidental sampling technique is used to gain this sample. The measurement of this study are Social Provisions Scale (translated to Indonesia's language) for familial social support and Health Motivation in Physical Activity (translated to Indonesia's language) for health-maintaining motivation. 
Result showed that familial social support has significant role to healthmaintaining motivation through physical activity in elderly people $\left(R^{2}=0.072 ; p=<0.05\right)$. The result suggested that familial social support has $7.2 \%$ contribution to health-maintaining motivation through physical activity in elderly people.

\section{PENDAHULUAN}

Kesehatan adalah hal terpenting dalam kehidupan manusia. Namun sayangnya, terkadang individu kurang menjaga kesehatan sehingga timbul penyakit. Salah satu faktor yang mempengaruhi kesehatan manusia adalah faktor usia.

Dalam aspek kesehatan, semakin bertambahnya usia, semakin banyak pula keluhan mengenai kesehatan. Data yang didapatkan pada Badan Pusat Statistik tahun 2014 menyatakan, sebanyak 37.11 persen penduduk usia 45-65 tahun mengalami keluhan kesehatan selama satu bulan terakhir. Individu dengan usia 60-69 tahun yang mengalami keluhan kesehatan adalah sebanyak 48.49 persen, usia 70-79 tahun sebesar 57.65 persen, dan usia 80-89 tahun sebesar 64.01 persen.. Ilmuwan sosial menyebutkan bahwa individu yang berkisaran 60 tahun ke atas tersebut sebagai kelompok dewasa akhir atau lansia (Papalia, Old, dan Feldman, 2013).

DKI Jakarta merupakan salah satu kualifikasi kota besar di antara 14 kota yang populasi lanjut usianya cukup tinggi (Surveymeter, 2013). Hal ini dapat terjadi salah satunya karena, dipengaruhi oleh semakin meningkatnya usia harapan hidup di Jakarta yang sudah mencapai 69,2 tahun. Data tersebut mendekati usia harapan hidup nasional yang mencapai 70,7 tahun (Surveymeter, 2016). Bertambahnya jumlah lansia ini dapat menjadi hal yang positif jika lansia dalam keadaan sehat, sedangkan apabila dalam keadaan sakit, maka potensi kerugian dari pembiayaan Jaminan Kesehatan Nasional (JKN) juga akan meningkat (Sulaiman, 2016). Biaya ini semakin meningkat apabila usia harapan hidup lansia bertambah (Ambardini, 2009).

Tingginya keluhan kesehatan yang dialami oleh lansia membuat lansia dituntut untuk menjaga kesehatan, seperti menjalankan aktivitas fisik yaitu olahraga yang teratur, melakukan pola hidup yang sehat, tidak merokok, dan pemeriksaan kesehatan secara rutin. Selain untuk kepentingan tubuh, kesehatan yang baik pada lansia juga dapat menciptakan lansia yang produktif, dan sekaligus menggambarkan bagaimana tingkat kualitas hidup lansia tersebut. Kondisi fisik yang semakin renta membuat lansia merasa kehidupannya sudah tidak berarti lagi dan putus asa dengan kehidupan yang dijalani saat ini (Rohmah, Purwaningsih, Bariyah, 2012).

Manfaat aktivitas fisik pada lansia yaitu dapat memperpanjang usia, menyehatkan jantung, otot, dan tulang, membuat lansia lebih mandiri, mencegah obesitas, mengurangi kecemasan dan depresi, juga memperoleh kepercayaan diri yang lebih tinggi (Ambardini, 2009). Jenis aktivitas fisik yang sesuai bagi lansia adalah aktivitas yang sifatnya aerobic seperti jalan kaki, berenang, dan senam (Sumintrasih, 2011). Namun sayangnya, tidak semua lansia mau melakukan aktivitas fisik secara rutin. Pentingnya beraktivitas fisik di masa lansia sejalan dengan penelitian yang dilakukan di Norwegia terhadap 5700 lansia yang berusia 68-77 tahun. Lansia yang rutin melakukan olahraga dalam seminggu dapat meningkatkan usia harapan hidupnya kurang lebih 5 tahun dibandingkan mereka yang malas bergerak (Anwar, 2015).

Menurut Gage dan Berliner (dalam Shaleh, 2004), individu yang memiliki daya dorong untuk memunculkan perilaku dan memiliki arah dari proses perilaku tersebut sehingga mampu mancapai tujuannya maka individu tersebut dikatakan memiliki motivasi. Terkait kesehatan, motivasi menjaga kesehatan pada lansia adalah 
dorongan pada lansia yang dapat memunculkan perilaku sehat guna mewujudkan keadaan fisik, mental, dan sosial yang sejahtera. Motivasi menjaga kesehatan memiliki peran yang besar terhadap perilaku sehat. Sherman, Mann, dan Updegraff (dalam Xu, 2009) menyatakan bahwa orientasi motivasi kesehatan mempengaruhi perilaku sehat pada seorang lansia. Penilaian motivasi itu sendiri sering dikaitkan dengan ancaman kesehatan yang mepengaruhi perilaku sehat (Croyle dalam Xu, 2009).

Dukungan dari berbagai sumber sangat dibutuhkan lansia dalam menjaga kesehatannya, seperti misalnya dukungan sosial. Dukungan sosial datang dari sumber-sumber yang berbeda, seperti dari pasangan atau orang yang dicintai, keluarga, teman, co-workers, psikolog atau anggota organisasi. Dengan adanya dukungan sosial dari berbagai sumber, individu akan merasa yakin bahwa dirinya dicintai, disayangi, dihargai, bernilai, dan menjadi bagian dari jaringan sosial (Purba, Yulianto, dan Widyanti, 2007). Dukungan keluarga memiliki peran yang besar dalam kehidupan lansia. Hurlock (2003) menyebutkan bahwa kebutuhan psikologis dalam pola hidup lansia akan terpenuhi apabila mereka didekatkan dengan kerabat keluarga dan teman-teman sehingga memungkinkan mereka untuk sering berkomunikasi.

Dukungan dari keluarga merupakan unsur terpenting dalam membantu individu menyelesaikan masalah. Apabila ada dukungan, rasa percaya diri akan bertambah dan dapat memotivasi lansia dalam menjaga kesehatannya melalui aktivitas fisik (Stuart \& Sundeen dalam Mangasi, 2013). Pentingnya dukungan sosial dari kerabat terdekat lansia dapat membangun persepsi bahwa mereka masih diharga, dicintai, dan dihormati. Pada penelitian ini peneliti ingin mengetahui lebih lanjut peran dukungan keluarga terhadap motivasi menjaga kesehatan pada lansia melalui aktivitas fisik.

\section{METODE PENELITIAN}

\section{Tipe dan Rancangan Penelitian}

Tipe penelitian ini menggunakan penelitian korelasional. Korelasi itu sendiri merupakan angka yang menunjukan arah dan kuatnya hubungan antar dua variabel atau lebih. Arah dinyatakan positif atau negatif, sedangkan kuatnya hubungan dinyatakan dalam besarnya koefesien korelasi (Sugiyono,2010).

\section{Identifikasi Variabel Penelitian}

Variabel 1 : Dukungan Sosial Keluarga

Variabel 2 : Motivasi Menjaga Kesehatan

\section{Partisipan Penelitian}

Sampel penelitian ini adalah individu yang masuk dalam kategori lansia dini dan lanjut menurut Hurlock (2003) yaitu berusia 60-70 tahun dan diatas 70 tahun. Karakteristik sampel lain adalah berdomisili di DKI Jakarta dan minimal tinggal dengan 1 anggota keluarga, namun tidak ada batasan terkait jenis kelamin.

\section{Prosedur Penelitian}

Pada penelitian ini, peneliti mendatangi beberapa kegiatan lansia yang diadakan di setiap daerah di Jakarta, seperti posyandu lansia, dan senam lansia. Di daerah Jakarta Pusat dan Jakarta Selatan, peneliti mendatangi tempat tinggal lansia dari pintu ke pintu. Pada lansia yang bertemu dengan peneliti secara lansung, setiap aitem dibacakan oleh peneliti karena penglihatan lansia yang sudah terbatas, dan efektivitas waktu pengambilan data. Selebihnya, peneliti juga menggunakan kuisioner secara online untuk disebar ke beberapa lansia yang masih bisa menggunakan gadget.

\section{Instrumen Penelitian}

\section{Dukungan Sosial Keluarga}

Penelitian ini menggunakan modifikasi dari alat ukur social provisions scale. Social Provisions Scale dikembangkan oleh Cutrona dan Russel (1987) untuk mengukur ketersediaan 
dukungan sosial keluarga yang diperoleh dari hubungan individu dengan keluarga dengan mengukur enam dimensi social support yaitu attachment, social integration, reasurance of worth, reliable alliance, guidance, dan opportunity for nurturance. Instrumen penelitian ini menggunakan format skala Likert, antara lain: Sangat Tidak Setuju (STS), Tidak Setuju (TS), Setuju (S), dan Sangat Setuju (SS) dan memiliki jumlah aitem sebanyak 24 aitem.

\section{Motivasi Menjaga Kesehatan Melalui Aktivitas Fisik}

Penelitian ini menggunakan alat ukur health motivation in physical activity yang diadaptasi ke bahasa Indonesia. Motivasi menjaga kesehatan melalui aktivitas fisik dikembangkan oleh Xu (2009) untuk mengukur empat dimensi motivasi kesehatan yaitu health motivational tendency, health intention, action initiation motivation, dan persistence motivation. Instrumen penelitian ini menggunakan format skala Likert, antara lain: Sangat Tidak Sesuai (STS), Agak Tidak Sesuai (ATS), Natural (N), Agak Sesuai (AS), dan Sangat Sesuai (SS) dan aitem ini berjumlah 30 aitem.

\section{Metode Analisis Data}

Analisis data yang dilakukan adalah analisis regresi Uji Regresi Ganda. Uji regresi ganda dilakukan meramalkan bagaimana keadaan (naik - turunnya) variabel motivasi menjaga kesehatan melalui aktivitas fisik, bila dukungan sosial keluarga sebagai faktor prediktor dimanipulasi (dinaik - turunkan nilainya).

\section{ANALISIS \& HASIL \\ Data Demografis}

Partisipan penelitian ini berjumlah 101 orang dengan kisaran usia 60-84 tahun $(\mathrm{M}=65,64 ; \mathrm{SD}=5,973)$ di Jakarta. Mayoritas responden berjenis kelamin perempuan $(65,3 \%)$, dan mayoritas usia lansia masuk ke dalam kategori lansia dini (82,2\%). Sebagian besar responden berdomisili di
Jakarta Utara (44,6\%), dan mayoritas pendidikan terakhir reponden adalah hanya sampai sekolah dasar (SD) $(33,7 \%)$. Bila dilihat jumlah keluarga yang tinggal dengan responden adalah mayoritas masuk ke dalam kategori 1 (53.5\%), yakni responden hanya tinggal dengan 1 kelompok anggota keluarga (mis : hanya tinggal dengan anak). Dalam kehidupan sehari-hari kebanyakan yang berperan dalam kehidupan responden adalah orang lain $(65,3 \%)$ misalnya seperti anaknya, cucunya, atau pasangannya. Mayoritas responden berasal dari pulau Jawa $(92,1 \%)$. Pendapatan setiap bulan responden berada pada kisaran Rp 1-2Juta $(35,6 \%)$. Mayoritas responden melakukan aktivitas fisik $(75,2 \%)$ dan kebanyakan dari responden mengaku tidak memiliki penyakit serius $(63,4 \%)$.

\section{Hasil Uji Normalitas dan Linieritas}

Data dukungan sosial keluarga (per dimensi) dan motivasi menjaga kesehatan melalui aktivitas fisik berdistribusi normal $(\mathrm{p}>0.05)$.

Hasil uji linieritas terhadapAttachment, Social Integration, Guidance, dan Opportunity for Nurturance dari dukungan sosial keluarga memiliki hubungan yang linier terhadap motivasi menjaga kesehatan melalui aktivitas fisik. Sedangkan dimensi Reassurance of Worth, dan Reliable Alliance dari dukungan sosial keluarga tidak memiliki hubungan yang linier terhadap motivasi menjaga kesehatan melalui aktivitas fisik.

\section{Hasil Uji Regresi Ganda}

Pada uji regresi berganda ini peneliti hanya menganalisis kombinasi dimensi attachment, social integration, guidance, dan opportunity for nurturance. Karena memiliki hubungan linier terhadap motivasi lansia menjaga kesehatan melalui aktivitas fisik. nilai $(-1,157 \mathrm{X} 1)$ adalah koefisien regresi yang menunjukkan jika setiap penambahan 1 nilai angka untuk dimensi Attachment sementara dimensi lainnya konstan, maka akan ada penurunan motivasi menjaga kesehatan pada lansia 
sebanyak -1,157. Lalu nilai 1,914X2 adalah koefisien regresi yang menunjukkan jika setiap penambahan 1 nilai angka untuk dimensi Social Integration sementara dimensi lainnya konstan, maka akan ada kenaikan motivasi menjaga kesehatan pada lansia sebanyak 1,914 . Nilai $0,894 \mathrm{X}$ adalah koefisien regresi yang menunjukkan jika setiap penambahan 1 nilai angka untuk dimensi Guidance sementara dimensi lainnya konstan, maka akan ada kenaikan motivasi menjaga kesehatan pada lansia sebanyak 0,894 . Lalu yang terakhir nilai 1,380X4 adalah koefisien regresi yang menunjukkan jika setiap penambahan 1 nilai angka untuk dimensi Opportunity for Nurturance sementara dimensi lainnya konstan, maka akan ada kenaikan motivasi menjaga kesehatan pada lansia sebanyak 1,380. Kesimpulan dari hasil analisis tersebut adalah dimensi dukungan sosial keluarga yang paling berkontribusi terhadap motivasi lansia menjaga kesehatan melalui aktivitas fisik adalah social integration $(1,914)$.

\section{DISKUSI}

Dukungan sosial keluarga memiliki beberapa dimensi. Hasil analisis penelitian menunjukkan bahwa empat dari enam dimensi dukungan sosial keluarga yang diperoleh responden memiliki peran terhadap naik/turunnya motivasi menjaga kesehatan melalui aktivitas fisik. Empat dimensi tersebut diantaranya adalah attachment (kelekatan), social integration (integrasi sosial), guidance (bimbingan), dan opportunity for nurturance (kesempatan untuk mengasuh). Sedangkan dimensi reassurance of worth/pengakuan keahlian, reliable alliance (aliansi kepercayaan) tidak berkontribusi secara signifikan terhadap motivasi lansia menjaga kesehatan melalui aktivitas fisik.

Dimensi attachment adalah perasaan kasih sayang dan cinta yang diterima oleh lansia sehingga akan menimbulkan rasa aman bagi lansia (Cutrona dan Russel, 1987). Pada penelitian ini nilai koefisien regresi untuk dimensi attachment sebesar (-
1.157XI) yang artinya bahwa setiap penambahan 1 skor angka pada dimensi ini, makan akan ada penurunan motivasi menjaga kesehatan melalui aktivitas fisik pada lansia sebesar 1.157. Hal ini menunjukkan bahwa semakin lansia menerima dukungan sosial keluarga berupa attachment maka motivasi lansia untuk menjaga kesehatannya melalui aktivitas fisik menurun. Hasil ini menjadi menarik karena tidak sesuai dengan penelitian yang telah dilakukan oleh French, Smith, dan Cox (2011) yang menjelaskan bahwa attachment adalah salah satu hal yang memiliki peran terhadap motivasi melakukan aktivitas fisik.

Dimensi lain dari dukungan sosial keluarga yang memiliki peran terhadap motivasi menjaga kesehatan melalui aktivitas fisik adalah guidance. Hasil penelitian menunjukkan bahwa semakin tinggi guidance yang diperoleh lansia, maka semakin termotivasi lansia dalam menjaga kesehatan melalui aktivitas fisik. Guidance sendiri adalah aspek yang memungkinkan individu mendapatkan informasi, saran dan nasihat yang diperlukan (Cutrona dan Russel, 1987), sehingga apabila lansia mendapatkan halhal tersebut maka akan memacu dirinya untuk menjaga kesehatan, salah satunya dengan melakukan aktivitas fisik.

Opportunity for nurturance adalah salah satu dimensi dari dukungan sosial yang juga memberikan kontribusi terhadap motivasi lansia dalam menjaga kesehatan melalui aktivitas fisik. Hasil menunjukkan bahwa semakin tinggi dimensi ini diperoleh lansia maka semakin termotivasi untuk menjaga kesehatan melalui aktivitas fisik.

Dimensi dukungan sosial yang paling berperan dalam motivasi menjaga kesehatan melalui aktivitas fisik adalah social integration. Hasil penelitian menunjukkan bahwa semakin tinggi lansia mendapatkan dimensi ini maka semakin termotivasi untuk menjaga kesehatan melalui aktivitas fisik. Social integration sendiri merujuk pada dukungan yang menimbulkan perasaan memiliki sebagai bagian dari 
keluarga atau merasa dirinya sebagai tempat berbagi minat dan aktivitas (Cutrona, dan Russel, 1987). Hal tersebut menunjukkan ada ikatan yang dirasakan oleh lansia dengan anggota keluarganya, dan ikatan dalam keluarga sendiri dapat memberikan kenyamanan, keamanan, kesenangan dan berdampak positif bagi kesehatan (Weiss, 1974), dalam hal ini mendorong untuk menjaga kesehatan.

Hasil analisis data untuk mengetahui apakah skor dukungan sosial akan berbeda apabila didasarkan pada data demografi menunjukkan bahwa jumlah anggota keluarga yang tinggal dengan para lansia tidak menunjukkan skor dukungan sosial yang berbeda. Dalam kata lain, hasil tersebut menunjukkan berapapun jumlah anggota keluarga yang tinggal dengan dengan lansia, tidak membuat persepsi lansia berbeda tentang dukungan sosial keluarga yang ia terima. Meskipun kontribusinya masih di bawah $10 \%$, namun dukungan sosial keluarga tersebut tetap ada pengaruhnya terhadap motivasi lansia menjaga kesehatannya.

Hasil dari penelitian ini sejalan dengan penelitian yang dilakukan oleh Partikwo, Pietojo, dan Widjanarko (2006). Mereka menyatakan bahwa dukungan sosial keluarga sangat berperan guna meningkatkan perilaku sehat untuk lansia yang kebanyakan (70\%) tinggal dengan anggota keluarga. Hasil dari penelitian tersebut menjelaskan bahwa memang adanya peran dukungan sosial keluarga terhadap motivasi lansia menjaga kesehatan pada lansia. Individu membutuhkan dukungan sosial yang dimana salah satunya berasal dari keluarga (Sarafino, 1998).Apabila ada dukungan, rasa percaya diri akan bertambah dan motivasi untuk mengatasi masalah yang terjadi akan meningkat salah satunya masalah terkait kesehatan (Tamher dan Noorkasiani, 2009).

Motivasi kesehatan diorientasikan dengan dampak dari perubahan perilaku sehat (Sherman, Mann, and Updegraff, 2006). Perilaku sehat yang dijelaskan adalah aktivitas fisik. Cox $(1982 ; 1986)$ menegaskan pentingnya motivasi menjaga kesehatan melalui aktivitas fisik dan mengatakan bahwa faktor intrinsik adalah hal utama untuk perilaku sehat. Dukungan sosial keluarga yang diperoleh lansia berkontribusi $7,2 \%$ terhadap motivasi menjaga kesehatan melalui aktivitas fisik yang artinya $92,8 \%$ di pengaruhi oleh faktor lain. Artinya 92,8\% faktor lain tersebut bisa merupakan faktor intrinsik atau faktor ekstrinsik lain di luar persepsi dukungan sosial keluarga yang diterima.

Penelitian ini dapat memberikan manfaat berupa gambaran terkait aspek yang dapat berkontribusi terhadap perilaku sehat pada individu yang sudah masuk dalam usia lanjut, yaitu salah satunya adalah dukungan sosial keluarga. Peran sebesar $7.2 \%$ dari dukungan sosial keluarga membuka peluang bagi peneliti selanjutnya untuk mengeksplorasi aspek lain yang dapat berkontribusi terhadap perilaku sehat lansia, terutama terkait motivasi menjaga kesehatan melalui aktivitas fisik. Di sisi lain, masih terdapat beberapa kelemahan dalam penelitian yaitu belum meratanya jumlah sampel penelitian yang mewakili tiap wilayah di Jakarta sehingga belum dapat diambil kesimpulan menyeluruh terkait hasil penelitian yang menyebutkan sampel berdomisili di Jakarta.

\section{SIMPULAN}

1. Hasil penelitian menunjukkan terdapat empat dimensi dukungan sosial keluarga yang berkontribusi secara bersama-sama terhadap motivasi menjaga kesehatan. Dimensi tersebut adalah attachment, social integration, guidance, dan opportunity for nurturance. Sedangkan 2 dimensi lain yaitu reassurance of worth dan reliable alliance tidak signifikan berperan pada motivasi lansia dalam menjaga kesehatan melalui aktivitas fisik

2. Belum dilakukan eksplorasi teoritis mendalam terkait 2 dimensi dari dukungan sosial keluarga yang tidak memberikan kontribusi terhadap motivasi menjaga kesehatan melalui aktivitas fisik pada lansia. 


\section{SARAN}

- Secara teoritis, perlu dilakukan eksplorasi mendalam melalui riset lanjutan untuk mengetahui dimensidimensi dari dukungan sosial keluarga yang berdasarkan penelitian ini tidak memberikan kontribusi signifikan terhadap motivasi menjaga kesehatan melalui aktivitas fisik.

- Penelitian ini dapat dijadikan sebagai landasan yang tepat dalam merancang promosi kesehatan terkait faktor-faktor yang mempengaruhi motivasi menjaga kesehatan melalui aktivitas fisik pada lansia.

- Guna meningkatkan motivasi menjaga kesehatan lansia melalui aktivitas fisik pada lansia, anggota keluarga disarankan lebih memperhatikan keberadaan lansia sebagai anggota keluarga. Hal tersebut dapat membangun rasa saling memiliki antar lansia dengan anggota keluargnya, sehingga dapat memotivasi lansia untuk menjaga kesehatannya untuk melakukanaktivitas fisik.

\section{DAFTAR PUSTAKA}

Ambardini, R. L. (2009). Aktivitas fisik pada lanjut usia. Yogyakarta: Universitas Negeri Yogyakarta.

Cox, C. (1982). An interaction model of client health behavior: Theoretical prescription for nursing. Advances in Nursing Science, 5, 41-56. (published)

Cox, C. (1986). The interaction model of client health behavior: Application to the study of community-based elders. Advances in Nursing Science, 9, 4057. (published)

Cutrona, C. E., \& Russel, D. W. (1987). The provisions of social relationships and adaptation to stress. Advances in personal relationship, 1, 37-67. (published)
Hurlock, E. B. (2003). Psikologi Perkembangan edisi lima. Jakarta: Penerbit Erlangga

Friedman, M. (1998). Keperawatan keluarga teori dan praktik (family nursing: theory and practice) edisi 3. Jakarta: EGC. (published)

Mangasi, A. (2013). Hubungan antara dukungan keluarga dengan motivasi lansia dalam mempertahankan kualitas hidup lansia di rw 05 kelurahan paseban kecamatan senen jakarta pusat 2012. Skripsi. Jakarta: STIK Saint Carolus (published)

Papalia, D.E., Olds, S.W., \& Feldman, R.D. (2013). Human development perkembangan manusia edisi $10 \mathrm{buku}$ 2. Jakarta: Penerbit Salemba Humanika

Partikwo, S., Pietojo, H., \& Widjanarko, B. (2006). Analisis pengaruh faktor nilai hidup, kemandirian, dan dukungan keluarga terhadap perilaku sehat lansia di kelurahan medono kota Pekalongan. Jurnal Promosi Kesehatan Indonesia, vol 1. (published)

Purba, J., Yulianto, A., \& Widyanti, E. (2007). Pengaruh dukungan social terhadap burnout pada guru. Jurnal Psikologi Vol. 5 No. 1. (published)

Rohman, A.I.N., Purwaningsih., \& Bariyah, K. (2012). Kualitas hidup lansia. Jurnal Kepererawatan. 2086-3071 (published)

Russell, D., \& Cutrona, C. E., Rose, J., \& Yurko, K (1984). Social and emotional loneliness: An examination of Weiss's typology of loneliness. Journal of Personality and Social Psychology, 6, 1313-1321. (published) 
Sarafino E. (1998). Health psycology : biopsychosocial interaction. New York : John Wiley \& Sons, Inc.

Shaleh, A.R. (2004). Psikologi: suatu pengantar dalam perspektif Islam. Jakarta: Kencana

Sherman, D. K., Mann, T., \& Updegraff, J. A. (2006). Approach/avoidance motivation, message framing, and health behavior: Understanding the congruency effect. Motivation and Emotion, 30, 165-169. (published)

Sugiyono. (2007). Metode penelitian administrasi. Bandung: ALFABETA.

(2010). Statistik untuk penelitian. Bandung: ALFABETA.

(2012). Statistika untuk penelitian. Bandung: ALFABETA.

Sumintrasih. (2011). Kebugaran jasmani untuk lanjut usia. Yogyakarta: UPN "Veteran" Yogyakarta. (published)

Sunjoyo, S.,et al. (2013). Aplikasi SPSS untuk smart riset (Program IBM SPSS 21.0). Bandung: Alfabeta

Tamher, \& Noorkasiani. (2009). Kesehatan usia lanjut dengan pendekatan asuhan keperawatan. Jakarta: Salemba Medika. (published)

Weiss, R. (1974). The provisions of social relationships. In Z. Rubin (Ed.), Doing unto others (pp. 17-26). Englewood Cliffs, NJ: Prentice Hall.

Xu, X. (2009). Health motivation in helath behavior: its theory and application. $U N L V$

Theses/Dissertation/Profesional

Papers/Capstones. $\quad$ Paper 42. (published)
Anwar, Firdaus. (2015). Rutin olahraga di hari tua bisa perpanjang umur sampai lima tahun. Diakses pada 18 Juli 2016 dari http://health.detik.com/read/2015/05/ 16/081426/2916229/763/rutin olahraga-di-hari-tua-bisa-perpanjangumur-sampai-lima-tahun

BKKBN. (2016). Pemutahkir data keluarga (2016). Diakses pada 28 November 2016 dari http://aplikasi.bkkbn.go.id/mdk/MDK Reports/KS/tabel102.aspx

Sulaiman, M.R. (2016). Usia harapan hidup di Indonesia meningkat, lansia semakin banyak. Diakses pada $29 \mathrm{Mei}$ 2016 dari https://health.detik.com/read/2016/05/ 26/174738/3218750/763/usiaharapan-hidup-di-indonesiameningkat-jumlah-lansia-makinbanyak

Surveymeter (2013). Satu langkah menuju impian lanjut usia, kota ramah lanjut usia 2030 (Kota Jakarta). Diakses pada 27 November 2016 dari http://surveymeter.org/read/103/satulangkah-menuju-impian-lanjut-usiakota-ramah-lanjut-usia-2030-kotajakarta-pusat

Correspondence:

Rizka Ahadiningtyas Juliana Atmaja, Universitas YARSI, Jakarta, Indonesia, Tel. 089693765567, Email: rizka.ahadiningtyas@gmail.com

\section{Alamat Redaksi Jurnal Psikogenesis}

Fakultas Psikologi, Universitas YARSI Jl. Letjen Suprapto, Cempaka Putih Jakarta Pusat. 10510 Telp: $021-4223138$

Email: jurnal.psikogenesis@yarsi.ac.id Web: http://academicjournal.yarsi.ac.id/ 